\title{
Serum uric acid and risk of cardiovascular mortality: a systematic review and dose- response meta-analysis of cohort studies of over a million participants
}

\author{
Fatemeh Rahimi-Sakak ${ }^{1}$, Mahsa Maroofi ${ }^{1}$, Jamal Rahmani ${ }^{1}$, Nick Bellissimo ${ }^{2}$ and Azita Hekmatdoost ${ }^{3}$ (D)
}

\begin{abstract}
Background: Cardiovascular disease (CVD) is the leading cause of death worldwide. Some studies have suggested anassociation between serum uric acid levels and cardiovascular mortality; however, the results have not been summarized in a meta-analysis.

Methods: A comprehensive search of all related studies until April 2018was performed in MEDLINE/PubMed and Scopus databases DerSimonianand Laird random-effects models were used to combine hazard ratios (HRs) with 95\% confidence intervals (Cls). Dose-response analysis was also carried out.

Results: Thirty-two studies containing forty-four arms with 1,134,073 participants reported association between uric acid and risk of CVD mortality were included in our analysis. Pooled results showed a significant positive association between uric acid levels and risk of CVD mortality (HR 1.45, 95\% Cl 1.33-1.58, $\mathrm{I}^{2}=79 \%$ ). Sub-group analysis showed this relationshipwasstronger in women compared to men. Moreover, there was a significant non-linear association between uric acid levels and the risk of CVD mortality ( $r=0.0709, p=0.001)$.
\end{abstract}

Conclusion: Our analysis indicates a positive dose-response association between SUA and CVD mortality risk.

Keywords: Uric acid, Serum uric acid, Cardiovascular diseases mortality, CVD mortality, Longitudinal, Cohort

\section{Background}

Cardiovascular diseases (CVD) are the first leading cause of death worldwide [1]. This might be due to an increased incidence of chronic diseases such as obesity, diabetes, hypertension, dyslipidemia, and hyperuricemia [2]. Uric acid (UA) is considered the ultimate product of purine metabolism in humans. Evidence suggests that increased levels of serum uric acid (SUA) are associated with the development of hypertension, coronary heart disease (CHD), cardiovascular stroke, cerebrovascular accidents (CVA), and cardiovascular disease [3].SUA concentrations can reflect the amount of purine intake from the diet, inborn purine metabolism, changes in UA secretion (reduced

\footnotetext{
* Correspondence: a_hekmat2000@yahoo.com

${ }^{3}$ Department of Clinical Nutrition and Dietetics, Faculty of Nutrition Sciences and Food Technology, National Nutrition and Food Technology Research Institute, ShahidBeheshti University of Medical Sciences, Tehran, Iran Full list of author information is available at the end of the article
}

glomerular filtration and tubular secretion, or increased tubular reabsorption), and intestinal degeneration [4]. The relationship between SUA and CVD was first reported more than 50 years ago, and several epidemiological studies were conducted to assess the association between hyperuricemia (HU) and CVD [5]. Although many studies have been conducted assessing the relationship between UA and CVD, there is disagreement about this relationship [6]. These controversies are due to the dual effect of UA in the body [7]. The atherogenic effects of UA include induction of oxidative stress in cells, which reduces the bioavailability of nitric oxide - associated with the activity of platelets and endothelial cells and the differentiation of smooth muscle cells in the vascular system. On the other hand, UA can also have antioxidant properties that can prevent atherosclerosis and improve endothelial function [8].

To gain a greater understanding of the prognostic value of SUA for future clinical decision making, we

(c) The Author(s). 2019 Open Access This article is distributed under the terms of the Creative Commons Attribution 4.0 International License (http://creativecommons.org/licenses/by/4.0/), which permits unrestricted use, distribution, and reproduction in any medium, provided you give appropriate credit to the original author(s) and the source, provide a link to the Creative Commons license, and indicate if changes were made. The Creative Commons Public Domain Dedication waiver (http://creativecommons.org/publicdomain/zero/1.0/) applies to the data made available in this article, unless otherwise stated. 


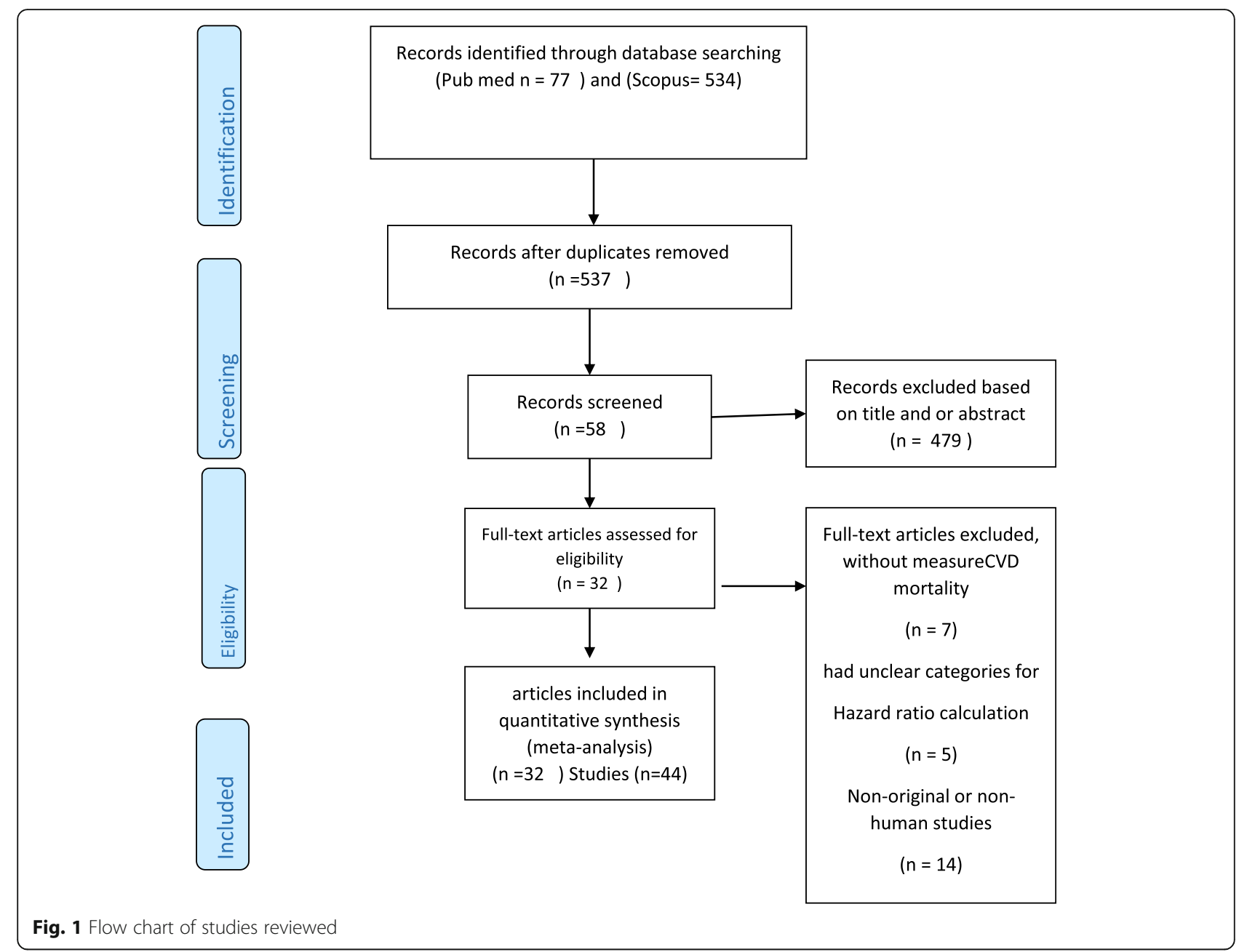

conducted a meta-analysis of prospective cohort studies with dose- response analysis to determine the relationship between SUA and CVD mortality.

\section{Methods}

This meta-analysis conducted by following the Metaanalysis of Observational Studies in Epidemiology study guidelines (MOOSE) [9]. A comprehensive literature search was carried out by two reviewers (MM) and (FRS) independently on PubMed/MEDLINE (https://www.ncbi. nlm.nih.gov/pubmed/) and Scopus (https://www.scopus. com/search/) databases up to April 2019 without any time restriction. Following keyword was followed for systematic search: in PubMed/MEDLINE: ((“"Uric Acid”[Mesh] OR uric acid [Title/Abstract]) OR serum uric acid [Title/Abstract]) AND (((“"cardiovascular disease mortality"[Title/ Abstract] OR "cardio vascular mortality"[Title/Abstract]) OR "cardiovascular mortality" [Title/Abstract]) OR "CVD mortality" [Title/Abstract]) OR CVD-mortality [Title/Abstract])) AND (((prospective [Title/Abstract] OR longitudinal [Title/Abstract]) OR follow-up [Title/Abstract]) OR cohort [Title/Abstract]), in Scopus: ((TITLE-ABS-KEY (prospective) OR TITLE-ABS-KEY (longitudinal) OR TITLE-ABS-KEY (follow-up) OR TITLE-ABS-KEY (cohort))) AND ((TITLE-ABS-KEY (uric AND acid) OR TITLE-ABS-KEY (serum AND uric AND acid))) AND ((TITLE-ABS-KEY (cardiovascular AND disease AND mortality) OR TITLE-ABS-KEY (cardiovascular AND mortality) OR TITLE-ABS-KEY (cardio AND vascular AND mortality) OR TITLE-ABS-KEY (cvd AND mortality) OR TITLE-ABS-KEY (cvd-mortality))).

\section{Exclusion and inclusion criteria and data extraction}

Non-English articles, reviews papers, editorials, non CVD mortality, non-human studies, in vitro research, case reports, and letters without sufficient data were excluded. Studies that met the following inclusion criteria were included in this meta-analysis:

1) Cohort study design with CVD mortality outcome.

2) Hazard ratio (HR) and the corresponding $95 \%$ confidence interval (CI) of CVD mortality were reported based on uric acid levels. 


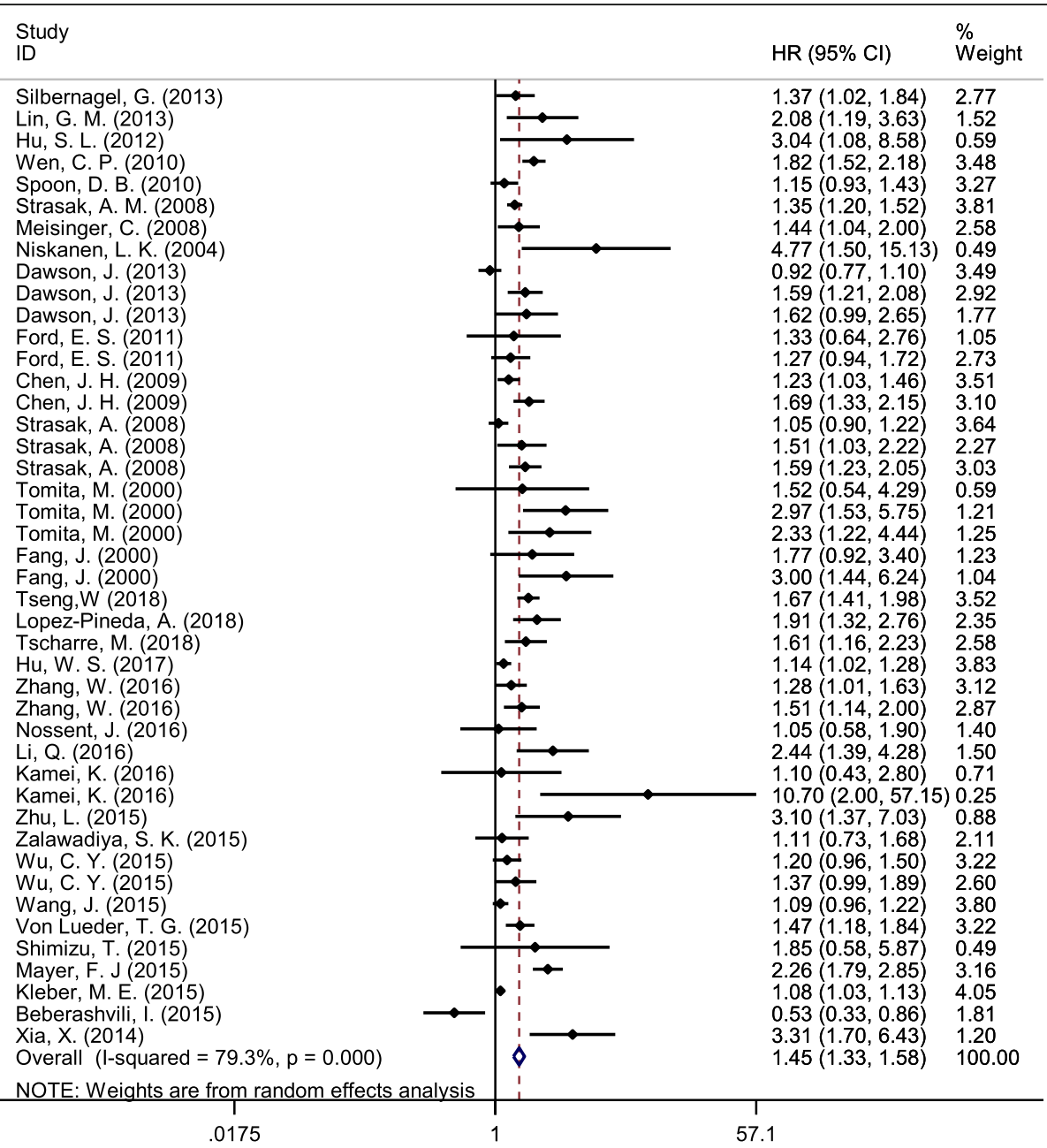

Fig. 2 The forest plot between highest versus lowest categories of serum uric acid and cardiovascular disease mortality

The first author, publication year, country, study design, number of participants, mean age, gender, years of follow-up, hazard ratios and 95\% CIs of CVD mortality information extracted from included studies.

\section{Statistical analysis}

The STATA 14.0 statistical software (Stata Corporation, College Station, Texas, USA) was used for statistical analyses. Combined results of hazard ratio of CVD mortality conducted by Random-effects model [10]. $P<0.10$ and $\mathrm{I} 2<\% 50$ were considered as heterogeneity detection among included studies. In order to find source of heterogeneity, subgroup analysis was conducted based on gender, whereas meta-regression analysis was conducted based on follow-up years, age of participants and HR of CVD mortality. Non-linear association was examined by modeling concentration level using restricted cubic splines [10]. The publication bias among included studies evaluated by Funnel plot, Begg's test, and Egger's regression test.

\section{Results}

Literature search

A flow chart of included studies is shown in Fig. 1. In the primary search 611 records were identified, after excluding 74 duplicates studies and 479 irrelevant studies from title and abstract screening, 58 studies remained for full text screening. After reviewing the full text, 26 studies were excluded because they did not meet the inclusion criteria. Finally, 32 studies, containing 44 arms and 1,134, 073 participants, were included in the meta analysis.

\section{Study characteristics and quality assessment}

Table 1 shows characteristics of included studies. Studies were published between 2000 and 2018. The mean age of participants was 55.9 years and the mean duration of follow-up was 9 years from 1 to 18 years. Seventeen studies were performed in Asia and Australia [11-27], and fifteen in Europe and America [28-42]. Twenty-two arms were conducted in both genders, eight in women, and fourteen in men. 
Table 1 Baseline Characteristics of Included Studies in the Meta-analysis

\begin{tabular}{|c|c|c|c|c|c|c|}
\hline Studies & Author & Year & Country & Follow up (year) & Sex (1-women, 2-men, 3-both) & Patients, $\mathrm{n}$ \\
\hline 1 & Silbernagel, G. & 2013 & Germany & 7.3 & 3 & 3245 \\
\hline 2 & Lin, G. M. & 2013 & Taiwan & 3.2 & 3 & 1054 \\
\hline 3 & Hu, S. L. & 2012 & Taiwan & 10 & 3 & 1093 \\
\hline 4 & Wen, C. P. & 2010 & Taiwan & 8.5 & 3 & 230,508 \\
\hline 5 & Spoon, D. B. & 2010 & USA & 2 & 3 & 1916 \\
\hline 6 & Strasak, A. M. & 2008 & Austria & 21 & 1 & 28,613 \\
\hline 7 & Meisinger, $C$. & 2008 & Germany & 11.7 & 2 & 3604 \\
\hline 8 & Niskanen, L. K. & 2004 & Finland & 11.9 & 2 & 1423 \\
\hline 9 & Dawson, J. & 2013 & Scotland & 10 & 1 and 2 & 6984 \\
\hline 10 & Ford, E. S. & 2011 & USA & 14 & 3 & 13,802 \\
\hline 11 & Chen, J. H. & 2009 & Taiwan & 8.2 & 1 and 2 & 90,393 \\
\hline 12 & Strasak, A. & 2008 & Austria & 13.6 & 2 & 83,638 \\
\hline 13 & Tomita, M. & 2000 & Japan & 5.4 & 2 & 49,413 \\
\hline 14 & Fang, J. & 2000 & USA & 16.4 & 1 and 2 & 5926 \\
\hline 15 & Tseng,W & 2018 & Taiwan & 5.8 & 3 & 127,771 \\
\hline 16 & Lopez-Pineda, A. & 2018 & Spain & 3 & 3 & 1119 \\
\hline 17 & Tscharre, M. & 2018 & Austria & 5.5 & 3 & 1215 \\
\hline 18 & Hu, W. S. & 2017 & china & 8.8 & 3 & 381,963 \\
\hline 19 & Zhang, W. & 2016 & Japan & 23 & 1 and 2 & 36,313 \\
\hline 20 & Nossent, J. & 2016 & Australia & 15 & 3 & 3475 \\
\hline 21 & Li, Q. & 2016 & china & 3.9 & 3 & 1799 \\
\hline 22 & Kamei, K. & 2016 & Japan & 8 & 1 and 2 & 3487 \\
\hline 23 & Zhu, L. & 2015 & china & 12 & 3 & 588 \\
\hline 24 & Zalawadiya, S. K. & 2015 & USA & 14.5 & 3 & 11,009 \\
\hline 25 & Wu, C. Y. & 2015 & Taiwan & 5 & 1 and 2 & 77,541 \\
\hline 26 & Wang, J. & 2015 & china & 6 & 3 & 2585 \\
\hline 27 & Von Lueder, T. G. & 2015 & Norway & 2.7 & 3 & 12,677 \\
\hline 28 & Shimizu, $\mathrm{T}$. & 2015 & Japan & 1.67 & 3 & 424 \\
\hline 29 & Mayer, F. J & 2015 & Austria & 6.3 & 3 & 959 \\
\hline 30 & Kleber, M. E. & 2015 & Germany & 10 & 3 & 3315 \\
\hline 31 & Beberashvili, I. & 2015 & Israel & 2 & 3 & 261 \\
\hline 32 & Xia, X. & 2014 & China & 2.1 & 3 & 985 \\
\hline
\end{tabular}

\section{Main results of the meta-analysis}

In 44 arms, pooled results from the random effects model showed a positive association between SUA and risk of CVD mortality in highest versus lowest category of SUA (HR 1.45, 95\% CI 1.33-1.58, I2 = 79\%) (Fig. 2). Subgroup analysis based on a gender showed a stronger relationship in women compared with men (Fig. 3). Meta-regression analysis did not show any significant relationship between SUA and risk of CVD mortality based on participant age $(p=$ 0.86 ) or duration of follow-up $(p=0.44)$.

\section{Dose-response analysis}

The pooled HR from the random-effects dose-response model of included studies showed a significant positive association between SUA and CVD mortality $(r=0.0709$, $p=0.001)$ (Fig. 4).

\section{Publication bias}

Figure 5 shows funnel plots of CVD mortality. There was publication bias among the studies (the Begg's $p=0.04$ and Egger's test). Using the 'Trim and fill' 


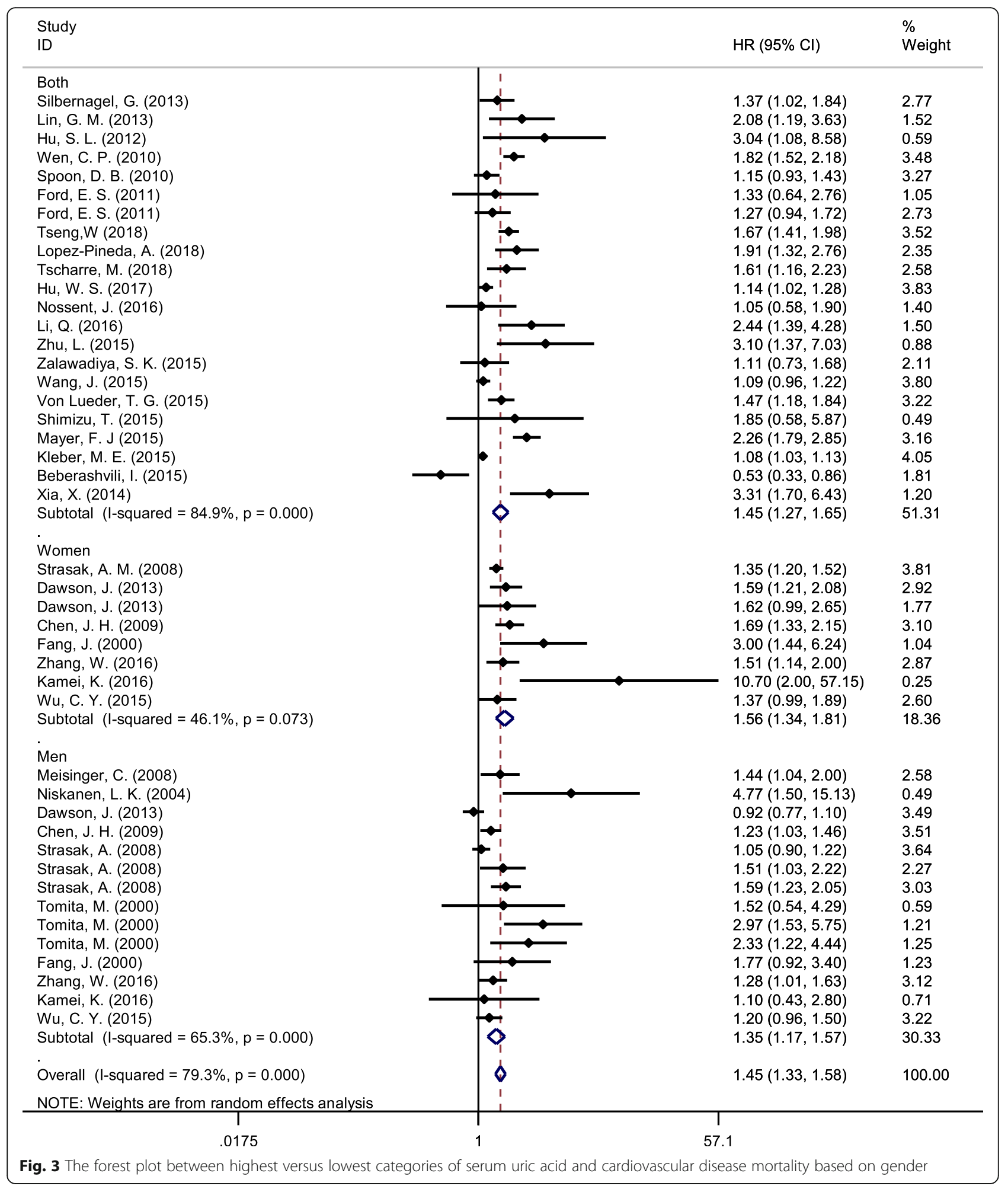

method to adjust for publication bias and random effects model showed 62 arms with pooled results $H R=$ 1.19 (CI:1.09-1.30).

\section{Discussion}

The present meta-analysis of cohort studies revealed that there is a strong relationship between SUA levels and 


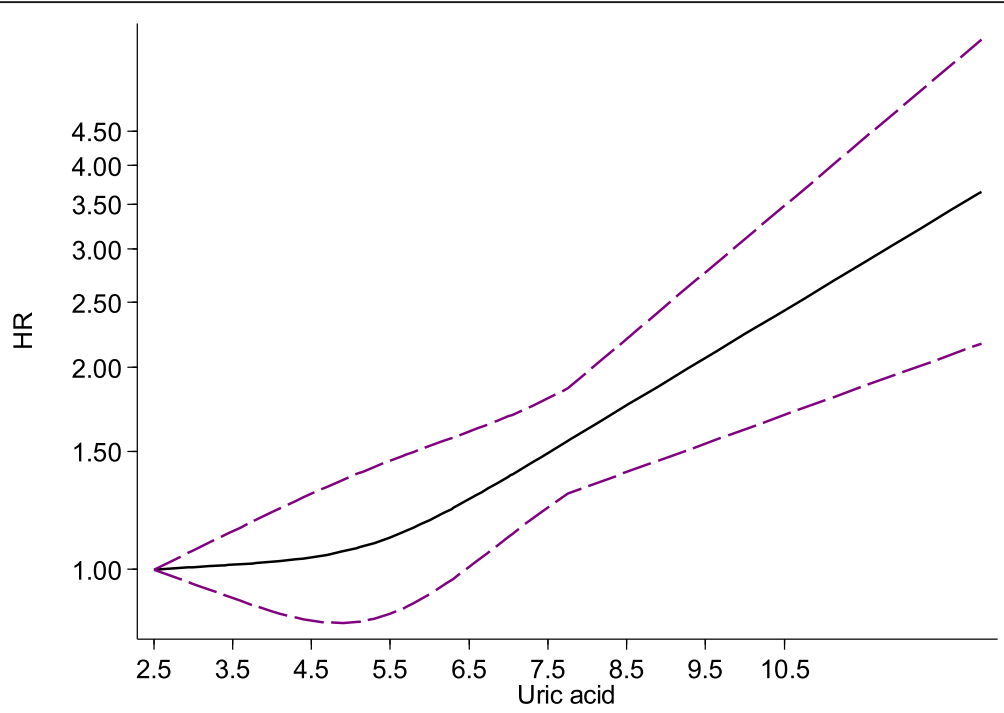

Fig. 4 Dose-response association between serum uric acid (mg/dL) and cardiovascular disease mortality (HR)

risk of CVD mortality. Moreover, the pooled HR from the random-effects dose-response model indicated that this positive association is stable when SUA is greater than $6 \mathrm{mg} / \mathrm{dL}$. Although the exact mechanism of the relationship between SUA and CVD mortality risk has not yet been elucidated, previous studies have suggested some possible explanations..

An experimental study has reported that using an inhibitor of uricase can elevate blood pressure in rats by activating the renin-angiotensin system and inhibition of nitric oxide synthase [43]. Moreover, it has been shown that patients with hypertension and hyperuricemia had higher carotid intima media thickness in comparison to patients without hyperuricemia [44]. Furthermore, it has been reported that blood atherosclerotic platelets consist of a great amount of UA and higher levels of SUA can simply boost thrombus development which may lead to slow coronary flow (SCF) [45]. In contrast, UA may have some anti-proliferative influence on the endothelium or can damage the process of nitric oxide production [16].

It has been suggested that UA can significantly slow down coronary flow by promoting the calcification of coronary arteries $[45,46]$. In addition, higher levels of SUA may induce oxidative stress by oxidation of lowdensity lipoprotein cholesterol which may lead to SCF [45]. Another possible mechanism might be explained



Fig. 5 Funnel plots to assessment publication bias 
by the effects of hyperuricemia in induction of crystal shaping on vascular walls that impair endothelial and smooth muscle function leading to atherosclerosis by renin-angiotensin system activation [43, 47]. Even, crystals of urate have several noxious effects that activate neutrophilsand macrophage cells to set proteases free and stimulate the coagulation cascade [48].

The main strength of this meta-analysis was the application of cohort studies containing over one million participants, and subsequent dose-response analysis. This study has some possible limitation. The heterogeneity in the study populations is the main limitation of this study. Moreover, the duration of follow-up in our included studies differed. Further, there is an insufficient number of randomized clinical trials to confirm the effects of decreasing SUA levels on CVD deaths; however, our results suggest higher levels of SUA is an independent risk factor associated with CVD mortality. Furthermore, although we searched the literature extensively, we did not explore grey or unpublished literature to limit the possibility of publication bias.

\section{Conclusion}

In conclusion, our analysis indicates a positive doseresponse association between SUA and CVD mortality risk; however, further clinical trials are needed to confirm these findings and to determine the possible causeeffect relationship.

\section{Abbreviations}

Cl: Confidence interval; CVD: Cardiovascular diseases; HR: Hazard ratio; SCF: Slow coronary flow; SUA: Serum uric acid; UA: Uric acid

\section{Acknowledgements}

This study is related to the project NO.1397/69621 from Student Research Committee, Shahid Beheshti University of Medical Sciences, Tehran, Iran. We also appreciate the "Student Research Committee" and "Research \& Technology Chancellor" at Shahid Beheshti University of Medical Sciences for their financial support of this study.

\section{Authors' contributions}

FR designed the study. FR, MM, JR, NB and $\mathrm{AH}$ were involved in the selection of publications and data collection for the meta-analysis. $\mathrm{AH}$ reviewed the selected studies. FR, JR, and MM participated in data analysis. $\mathrm{FR}$ and $\mathrm{AH}$ wrote the core manuscript, and all authors reviewed and approved of the final manuscript.

\section{Funding}

The study was supported financially by the "Student Research Committee" and "Research \& Technology Chancellor" at Shahid Beheshti University of Medical Sciences. The funding body did not play any role in design of the study, data analysis, and interpretation, and manuscript writing.

\section{Availability of data and materials}

All data are presented within the manuscript. Raw data can be available by corresponding author per request.

\section{Ethics approval and consent to participate}

Not applicable.

\section{Consent for publication}

Not applicable.

\section{Competing interests}

The authors declare that they have no competing interests.

\section{Author details}

${ }^{1}$ Student Research Committee, Faculty of Nutrition and Food Technology, Shahid Beheshti University of Medical Sciences, Tehran, Iran. ${ }^{2}$ School of Nutrition, Ryerson University, Toronto, Ontario, Canada. ${ }^{3}$ Department of Clinical Nutrition and Dietetics, Faculty of Nutrition Sciences and Food Technology, National Nutrition and Food Technology Research Institute, ShahidBeheshti University of Medical Sciences, Tehran, Iran.

Received: 8 July 2019 Accepted: 30 September 2019

Published online: 15 October 2019

\section{References}

1. Dhindsa DS, Khambhati J, Sandesara PB, Eapen DJ, Quyyumi AA. Biomarkers to predict cardiovascular death. Card Electrophysiol Clin. 2017;9(4):651-64 PubMed PMID: 29173408. Epub 2017/11/28.

2. Mora-Ramirez M, Estevez-Garcia IO, Irigoyen-Camacho ME, Bojalil R, Gonzalez-Pacheco H, Amezcua-Guerra LM. Hyperuricemia on admission predicts short-term mortality due to myocardial infarction in a population with high prevalence of cardiovascular risk factors. Rev Investig Clin. 2017; 69(5):247-53 PubMed PMID: 29077696. Epub 2017/10/28.

3. Zhao G, Huang $L$, Song M, Song $Y$. Baseline serum uric acid level as a predictor of cardiovascular disease related mortality and all-cause mortality: a meta-analysis of prospective studies. Atherosclerosis. 2013;231(1):61-8 PubMed PMID: 24125412. Epub 2013/10/16. eng.

4. Vassalle C, Mazzone A, Sabatino L, Carpeggiani C. Uric Acid for Cardiovascular Risk: Dr. Jekyll or Mr. Hide? Diseases. 2016;4(1) PubMed PMID: 28933392. Pubmed Central PMCID: PMC5456305. Epub 2016/02/26.

5. Braga F, Pasqualetti S, Ferraro S, Panteghini M. Hyperuricemia as risk factor for coronary heart disease incidence and mortality in the general population: a systematic review and meta-analysis. Clin Chem Lab Med. 2016;54(1):7-15 PubMed PMID: 26351943. Epub 2015/09/10.

6. Xu Q, Zhang M, Abeysekera IR, Wang X. High serum uric acid levels may increase mortality and major adverse cardiovascular events in patients with acute myocardial infarction. Saudi Med J. 2017;38(6):577-85 PubMed PMID: 28578435. Pubmed Central PMCID: PMC5541179. Epub 2017/06/05.

7. Kanbay M, Segal M, Afsar B, Kang DH, Rodriguez-Iturbe B, Johnson RJ. The role of uric acid in the pathogenesis of human cardiovascular disease. Heart. 2013;99(11):759-66 PubMed PMID: 23343689. Epub 2013/01/25.

8. Kei A, Koutsouka F, Makri A, Elisaf M. Uric acid and cardiovascular risk: What genes can say. Int J Clin Pract. 2018;72(1) PubMed PMID: 29250870. Epub 2017/12/19.

9. Stroup DF, Berlin JA, Morton SC, Olkin I, Williamson GD, Rennie D, et al. Meta-analysis of observational studies in epidemiology: a proposal for reporting. JAMA. 2000;283(15):2008-12.

10. Jackson D, White $I R$, Thompson SG. Extending DerSimonian and Laird's methodology to perform multivariate random effects meta-analyses. Stat Med. 2010;29(12):1282-97.

11. Beberashvili I, Sinuani I, Azar A, Shapiro G, Feldman L, Stav K, et al. Serum uric acid as a clinically useful nutritional marker and predictor of outcome in maintenance hemodialysis patients. Nutrition. 2015;31(1):138-47 English.

12. Chen JH, Chuang SY, Chen HJ, Yeh WT, Pan WH. Serum uric acid level as an independent risk factor for all-cause, cardiovascular, and ischemic stroke mortality: a Chinese cohort study. Arthritis Rheum. 2009;61(2):225-32 PubMed PMID: 19177541. Epub 2009/01/30. eng.

13. Hsu WL, Li SY, Liu JS, Huang PH, Lin SJ, Hsu CC, et al. High uric acid ameliorates Indoxyl sulfate-induced endothelial dysfunction and is associated with lower mortality among hemodialysis patients. Toxins. 2017; 9(1) PubMed PMID: 28067806. Pubmed Central PMCID: PMC5308252. Epub 2017/01/10. eng.

14. Hu SL, Liu CS, Lin CH, Davidson LE, Li Cl, Lin CC, et al. Uric acid and mortality in elderly chinese: a 10-year population-based cohort study. J Am Geriatr Soc. 2012;60(9):1783-5 English.

15. Kamei K, Konta T, Ichikawa K, Sato H, Suzuki N, Kabasawa A, et al. Serum uric acid levels and mortality in the Japanese population: the Yamagata (Takahata) study. Clin Exp Nephrol. 2016;20(6):904-9 PubMed PMID: 26779905. Epub 2016/01/19. eng.

16. Li Q, Zhang Y, Ding D, Yang Y, Chen Q, Liu C, et al. Association between serum uric acid and mortality among Chinese patients with coronary artery 
disease. Cardiology. 2016;134(3):347-56 PubMed PMID: 26985667. Epub 2016/03/18. eng.

17. Lin $G M$, Li YH, Zheng NC, Lai CP, Lin CL, Wang JH, et al. Serum uric acid as an independent predictor of mortality in high-risk patients with obstructive coronary artery disease. A prospective observational cohort study from the ET-CHD registry, 1997-2003. J Cardiol. 2013;61(2):122-7 English.

18. Nossent J, Raymond W, Divitini M, Knuiman M. Asymptomatic hyperuricemia is not an independent risk factor for cardiovascular events or overall mortality in the general population of the Busselton health study. BMC Cardiovasc Disord. 2016;16(1):256 PubMed PMID: 27978810. Pubmed Central PMCID: PMC5160002. Epub 2016/12/17. eng.

19. Shimizu T, Yoshihisa A, Kanno Y, Takiguchi M, Sato A, Miura S, et al. Relationship of hyperuricemia with mortality in heart failure patients with preserved ejection fraction. Am J Physiol Heart Circ Physiol. 2015;309(7): H1123-9 PubMed PMID: 26297226. Epub 2015/08/25. eng.

20. Tomita M, Mizuno S, Yamanaka H, Hosoda Y, Sakuma K, Matuoka Y, et al. Does hyperuricemia aeffect mortality? A prospective cohort study of japanese male workers. J Epidemiol. 2000;10(6):403-9 English.

21. Tseng WC, Chen YT, Ou SM, Shih CJ, Tarng DC, Yang CY, et al. U-shaped association between serum uric acid levels with cardiovascular and all-cause mortality in the elderly: The role of malnourishment. J Am Heart Assoc. 2018;7(4) English.

22. Wang J, Wang Y, Zhao D, Guo X, Zhong JQ. Association between serum uric acid and mortality in a Chinese population of hypertensive patients. Ren Fail. 2015:37(1):73-6 PubMed PMID: 25260057. Epub 2014/09/27. eng

23. Wen CP, David Cheng TY, Chan HT, Tsai MK, Chung WS, Tsai SP, et al. Is high serum uric acid a risk marker or a target for treatment? Examination of its independent effect in a large cohort with low cardiovascular risk. Am J kidney Dis. 2010;56(2):273-88 PubMed PMID: 20605302. Epub 2010/07/08. eng.

24. Wu CY, Hu HY, Chou YJ, Huang N, Chou YC, Lee MS, et al. High serum uric acid levels are associated with all-cause and cardiovascular, but not Cancer, mortality in elderly adults. J Am Geriatr Soc. 2015;63(9):1829-36 PubMed PMID: 26277576. Epub 2015/08/19. eng.

25. Xia X, He F, Wu X, Peng F, Huang F, Yu X. Relationship between serum uric acid and all-cause and cardiovascular mortality in patients treated with peritoneal dialysis. Am J Kidney Dis. 2014;64(2):257-64 PubMed PMID: 24176223. Epub 2013/11/02. eng.

26. Zhang W, Iso H, Murakami Y, Miura K, Nagai M, Sugiyama D, et al. Serum uric acid and mortality form cardiovascular disease: EPOCH-JAPAN study. J Atheroscler Thromb. 2016;23(6):692-703 PubMed PMID: 26887218. Epub 2016/02/19. eng

27. Zhu L, Wang J, Wang $Y$, Jia L, Sun $K$, Wang $H$, et al. Plasma uric acid as a prognostic marker in patients with hypertrophic cardiomyopathy. Can J Cardiol. 2015;31(10):1252-8 English.

28. Dawson J, Jeemon P, Hetherington L, Judd C, Hastie C, Schulz C, et al. Serum uric acid level, longitudinal blood pressure, renal function, and longterm mortality in treated hypertensive patients. Hypertension. 2013;62(1): 105-11 PubMed PMID: 23690348. Epub 2013/05/22. eng.

29. Fang J, Alderman MH. Serum uric acid and cardiovascular mortality the NHANES I epidemiologic follow-up study, 1971-1992. National Health and nutrition examination survey. JAMA. 2000;283(18):2404-10 PubMed PMID: 10815083. Epub 2000/05/18. eng.

30. Ford ES. Uric acid and mortality from all-causes and cardiovascular disease among adults with and without diagnosed diabetes: findings from the National Health and nutrition examination survey III linked mortality study. Diabetes Res Clin Pract. 2011;93(2):e84-e6 English.

31. Kleber ME, Delgado G, Grammer TB, Silbernagel G, Huang J, Krämer BK, et al. Uric acid and cardiovascular events: a Mendelian randomization study. J Am Soc Nephrol. 2015;26(11):2831-8 English.

32. Lopez-Pineda A, Cordero A, Carratala-Munuera C, Orozco-Beltran D, Quesada JA, Bertomeu-Gonzalez V, et al. Hyperuricemia as a prognostic factor after acute coronary syndrome. Atherosclerosis. 2018;269:229-35 PubMed PMID: 29407598. Epub 2018/02/07. eng.

33. Mayer FJ, Mannhalter C, Minar E, Schillinger M, Chavakis T, Siegert G, et al. The impact of uric acid on long-term mortality in patients with asymptomatic carotid atherosclerotic disease. I Stroke Cerebrovasc Dis. 2015;24(2):354-61 English.

34. Meisinger C, Koenig W, Baumert J, Döring A. Uric acid levels are associated with all-cause and cardiovascular disease mortality independent of systemic inflammation in men from the general population the MONICA ORA cohort study. Arterioscler Thromb Vasc Biol. 2008;28(6):1186-92 English.
35. Niskanen LK, Laaksonen DE, Nyyssonen K, Alfthan G, Lakka HM, Lakka TA, et al. Uric acid level as a risk factor for cardiovascular and all-cause mortality in middle-aged men: a prospective cohort study. Arch Intern Med. 2004; 164(14):1546-51 PubMed PMID: 15277287. Epub 2004/07/28. eng.

36. Silbernagel G, Hoffmann MM, Grammer TB, Boehm BO, Marz W. Uric acid is predictive of cardiovascular mortality and sudden cardiac death in subjects referred for coronary angiography. Nutr Metab Cardiovasc Dis. 2013;23(1): 46-52 PubMed PMID: 21703834. Epub 2011/06/28. eng.

37. Spoon DB, Lerman A, Rule AD, Prasad A, Lennon RJ, Holmes DR, et al. The association of serum uric acid levels with outcomes following percutaneous coronary intervention. J Interv Cardiol. 2010;23(3):277-83 English.

38. Strasak A, Ruttmann E, Brant L, Kelleher C, Klenk J, Concin H, et al. Serum uric acid and risk of cardiovascular mortality: a prospective long-term study of 83,683 Austrian men. Clin Chem. 2008;54(2):273-84 PubMed PMID: 18039719. Epub 2007/11/28. eng.

39. Strasak AM, Kelleher CC, Brant L, Rapp K, Ruttmann E, Concin H, et al. Serum uric acid is an independent predictor for all major forms of cardiovascular death in 28,613 elderly women: a prospective 21-year followup study. Int J Cardiol. 2008;125(2):232-9 English.

40. Tscharre M, Herman R, Rohla M, Hauser C, Farhan S, Freynhofer MK, et al. Uric acid is associated with long-term adverse cardiovascular outcomes in patients with acute coronary syndrome undergoing percutaneous coronary intervention. Atherosclerosis. 2018;270:173-9 English.

41. Von Lueder TG, Girerd N, Atar D, Agewall S, Lamiral Z, Kanbay M, et al. Serum uric acid is associated with mortality and heart failure hospitalizations in patients with complicated myocardial infarction: findings from the high-risk myocardial infarction database initiative. Eur J Heart Fail. 2015;17(11):1144-51 English.

42. Zalawadiya SK, Veeranna V, Mallikethi-Reddy S, Bavishi C, Lunagaria A, Kottam $A$, et al. Uric acid and cardiovascular disease risk reclassification: findings from NHANES III. Eur J Prev Cardiol. 2015;22(4):513-8 PubMed PMID: 24431384. Epub 2014/01/17. eng

43. Mazzali M, Kanellis J, Han L, Feng L, Xia Y-Y, Chen Q, et al. Hyperuricemia induces a primary renal arteriolopathy in rats by a blood pressure-independent mechanism. Am J Physiology Renal Physiol. 2002;282(6):F991-F7.

44. Tavil Y, Kaya MG, Oktar SÖ, Sen N, Okyay K, Yazıcı HU, et al. Uric acid level and its association with carotid intima-media thickness in patients with hypertension. Atherosclerosis. 2008;197(1):159-63.

45. Xia S, Deng SB, Wang $Y$, Xiao J, Du JL, Zhang $Y$, et al. Clinical analysis of the risk factors of slow coronary flow. Heart Vessel. 2011;26(5):480-6 PubMed PMID: 21207039. Epub 2011/01/06. eng.

46. Kaya EB, Yorgun H, Canpolat U, Hazirolan T, Sunman H, Ulgen A, et al. Serum uric acid levels predict the severity and morphology of coronary atherosclerosis detected by multidetector computed tomography. Atherosclerosis. 2010;213(1):178-83 PubMed PMID: 20863499. Epub 2010/ 09/25. eng.

47. Patetsios P, Song M, Shutze WP, Pappas C, Rodino W, Ramirez JA, et al. Identification of uric acid and xanthine oxidase in atherosclerotic plaque. Am J Cardiol 2001;88(2):188-191, a6. PubMed PMID: 11448423. Epub 2001/ 07/13. eng.

48. Gordon T, Terkeltaub R, Ginsberg M. Gout: crystal-induced inflammation. Inflammation: Basic Principles and Clinical Correlates New York, NY, Raven 1988:775-83.

\section{Publisher's Note}

Springer Nature remains neutral with regard to jurisdictional claims in published maps and institutional affiliations.

Ready to submit your research? Choose BMC and benefit from:

- fast, convenient online submission

- thorough peer review by experienced researchers in your field

- rapid publication on acceptance

- support for research data, including large and complex data types

- gold Open Access which fosters wider collaboration and increased citations

- maximum visibility for your research: over $100 \mathrm{M}$ website views per year

At $\mathrm{BMC}$, research is always in progress.

Learn more biomedcentral.com/submissions 